\title{
Position of the Board of Directors in Higher Education Institutions in Mongolia - Focusing on Analysis of Founder's Representatives
}

\author{
Jargalmaa Jargalsaikhan ${ }^{1}$ \\ ${ }^{1}$ Graduate School of Education, Kyoto University, Kyoto, Japan \\ Correspondence: Jargalmaa Jargalsaikhan, Graduate School of Education, Kyoto University, Kyoto, Japan. Tel: \\ 81-75-753-3094. E-mail: jargalsaikhan.jargalmaa.43c@st.kyoto-u.ac.jp
}

Received: August 1, 2021

doi:10.5539/hes.v11n4p19
Accepted: September 14, $2021 \quad$ Online Published: September 23, 2021

URL: https://doi.org/10.5539/hes.v11n4p19

\begin{abstract}
In 1995, during the process of democratization, Mongolia established a Law on Education and a Law on Higher Education. These laws positioned the board of directors as the ultimate decision-making body within each university and stipulated that the board's membership include the representatives of the university's founder, faculty members, students, parents, and alumni, enabling a wide range of people to participate in university governance. At the same time, it was stipulated that the representatives nominated by the founder would account for $51-60 \%$ of the board's membership, giving them a majority that runs counter to the principle of introducing greater diversity into the board. This article examines the positioning of the board of directors in Mongolian higher education institutions through reviews of documents and the websites of existing higher education institutions. In particular, this article clarifies the position of the board of directors as the mainstay of governance systems in both national and private universities in Mongolia. These findings are expected not only to further understanding of Mongolian higher education but also to furnish new insights into the board of directors as an organ for both internal control and external connection. This study offers implications for future research in the field of comparative education on higher education's governance reform in line with globalization and marketization.
\end{abstract}

Keywords: university reform, university governance, Mongolian higher education, founder's representatives, statutory document review

\section{Introduction}

Across the world, universities are in the midst of a dramatic transformation. In response to globalization and other rapid social changes, and especially the penetration of market competition principles, reforms to university governance are being pursued in many countries. With regard to specific reforms to the internal organization of universities, Ehara and Sugimoto (2005) observed that "in light of the trends in reform of university governance in the United States, it is possible to predict two major directions of such reform in other countries, including Japan. The first involves a major shift from collegial governance to corporate-style governance with a focus on efficiency and effectiveness. This means a narrowing of the authority and scope of free discretion afforded to university faculty members, and a strengthening of the authority of the board of directors and university administrators responsible for managing the university. The second is where the various external forces exerted on university reform cause the university's management policies and plans to be shaped increasingly by industry trends, governmental regulation, and other external influences. This causes a gradual weakening of institutional autonomy, both at the individual university level and across the university system as a whole, leading to the pursuit of heteronomous reforms. It is said that the image of universities as ivory towers is already a myth from the distant past, and universities will move to develop their proper ties with society at an even more profound level" (p.17; English translation by the author). The incorporation of diverse external opinions in internal organs of management, and the involvement of external experts are some of the topics relating to university governance discussed in recent years.

In this context, specifically with regard to the board of directors, the key management body of universities in Japan, Yamasaki (1996) states that "the board of directors is involved in managing financial resources and budgets, long-term plans, maintenance of facilities and equipment, and the like, and in this sense is deeply connected with various sectors of society such as government and the local community. The board is positioned 
between the university's academic organization and wider society, functioning as a bridge between the two and a buffer from society for the academic organization" (p.305-p.306).

In other words, the board of directors (hereafter "BoD") is thought to occupy a key position as the central node connecting the university to wider society, by promoting the involvement of external actors in the course of addressing social changes and marketization.

When viewed in this light, the BOD of higher education institutions (hereafter "HEIs") in Mongolia have several intriguing facets. Following a similar course to other countries, Mongolia went through a process of democratization and established a Law on Education and a Law on Higher Education in 1995. These positioned the $\mathrm{BoD}$ (Удирдах Зөвлөл) as the ultimate decision-making body within each university and stipulated that the board's membership include the representatives of the university's founder, faculty members, students, parents, and alumni, enabling a wide range of people to participate in university management and administration. This was a move to encourage representatives from the abovementioned categories to play a role in the university's key managerial body. At the same time, it was stipulated that the representatives nominated by the founder would account for $51-60 \%$ of the board's membership, giving them a majority. Thus, there is a need for further analysis of the positioning and practical composition of these boards in Mongolian HEIs, in the context of factors such as globalization and the introduction of market principles.

Classical theories of university governance include Cohen and Olsen's "organized anarchy," Burton Clark's "triangle model" (market, state authority, academic oligarchy) and McNay's model of university organizational culture (collegium, bureaucracy, corporation, enterprise) (Fujimura, 2008). Each of these presupposes that higher education is a priori independent of the market and the state, and each country or analysis is based on the local context regarding changes in the power relationships between governments, markets, and universities and the resulting changes in coordination.

In a previous study of Mongolian university governance, Baglan (2019) found that theBoD is nominally responsible for appointing the president in national universities, but in practice the appointment is done by a government agency. The same study notes, however, that the board does appoint the president in private universities. The study concludes that university autonomy has been promoted in the areas of academic programs, faculty and staff management and evaluation, student service admission and management, management procedures, decision-making structure, and finance. The study does not offer any concrete analysis of the authority of the board or explanation of the autonomy of the university. It does state that university governance is a multilevel process involving coordination by various actors and system levels in order to respond to globalization and marketization, but no explicit detail is provided.

A previous study that specifically examined the BoD (Munkh-erdene, 2008) is critical of the fact that 51-60\% of the directors appointed by the Ministry of Education and Science (hereafter "MECS") are made up of government officials and are strongly influenced by the government. This study considers an approach to governance of national universities that would achieve a break from political influence. According to this examination, while considering how to strengthen the administrative authority of teachers and how to promote privatization, it is better for universities to welcome members from other sectors of society to on their boards, as this would help them to break free from governmental influence. Furthermore, Baterdene \& Erdenebulgan (2018) point out that it is necessary to ensure the autonomy of national universities in Mongolia, and similar to Munkh-erdene (2008), they criticize the 51-60\% allocation of the founder's representatives.

In addition, Jargalmaa (2019) examines how the governance of national universities reflects the university management systems of both the socialist era (1921-1991) and the democratic era (1992-present). In the socialist era, universities were managed under the supervision of a committee of the People's Revolutionary Party established within each university, together with the university president, and presidential appointments and replacements were determined by the Party itself. Universities were positioned as institutions for the training of Party personnel, and university governance was influenced by the Party's ideology and principles. In contrast, the advent of the democratic era saw the introduction of a BoD designed to reflect a more diverse range of opinions and standpoints in university governance. Jargalmaa (2019) points out, however, that the fact that the majority of board members are government representatives means that the ideas of the party in government continue to be strongly reflected in the management of national universities, just as they were in the socialist era.

Prior research has thus shed some light on the issues of university governance models and the systems of management used in national universities in Mongolia, but has not focused on the main governance organization: The BoD. It has failed to analyze the actual situation of directors, examine private universities, or analyze how they differ from national universities. In addition, prior research has not shown how to respond to changes in the 
external environment such as globalization and marketization, and the position of the $\mathrm{BoD}$ with respect to these changes.

In light of the above, this article seeks to clarify the position of the $\mathrm{BoD}$ as the mainstay of governance systems in both national and private universities in Mongolia, through analysis of the composition of boards with a particular focus on the board members nominated by the university founder. This analysis is expected not only to further understand Mongolian higher education but also to furnish new insights into the $\mathrm{BoD}$ as an organ for both internal control and external connection, as universities address expectations for governance reform in line with globalization and marketization.

\section{Methods}

This research employed a combination of statutory document reviews and review of the websites of existing HEIs. First, the statutory framework of the 1995 Law on Education, 1995 Law on Higher Education, 2002 Law on Education, and 2002 Law on Higher Education, and the subsequent changes to these laws, were reviewed in order to examine the powers granted to the BoD. This review included an examination of the statutory provisions regarding board membership since the board of directors system was first adopted. Following this, the websites of existing HEIs were reviewed to analyze the composition of BoDs at both national and private HEIs in Mongolia, and especially the proportion of members as representatives nominated by the founder. Specifically, the characteristics of the BoD of all HEIs in Mongolia were organized by examining the information posted on the websites of HEIs $(\mathrm{N}=92)$ from January 1 to 14,2021 . Original information regarding the composition of the $\mathrm{BoD}$, posted on several websites, was not classified by the representatives of the founders, faculty members, or graduates. To confirm the accuracy of the information, key administrative HEIs $(\mathrm{N}=14)$ staff were contacted by phone (9 people) and by mail (5 people) between February 1 and 25, 2021 through the MECS' network.

\section{Results}

The analysis of the founder's representatives was conducted in several steps. First, the review of the statutory framework examined the powers afforded to the $\mathrm{BoD}$ in statutory terms, from the time the board of directors system was introduced through to the present day. On this basis, more details on the provisions pertaining to membership of the board were analyzed to explain how these provisions have changed over time. Second, the review of the existing HEIs' websites led to the following findings: (1) the composition of HEI boards, (2) the proportion of members nominated by the founder, and (3) comparative classification of institutional types based on the breakdown of members nominated by the founder.

\subsection{Board of Directors System and Changing Statutory Provisions on University Governance}

The BoD seems to play an important role as a management organ within HEIs in Mongolia. In order to shed light on the powers held by BoDs between the time they were adopted and the present day, this review begins by examining the provisions concerning the board's powers in the 1995 Law on Education and 1995 Law on Higher Education, which introduced the board of directors system. This is followed by an outline of the changes made to the system since, implementation of the 2002 Law on Education and 2002 Law on Higher Education, which have replaced the original laws.

First, the 1995 Law on Education stipulated that a BoD be established in institutions of education at all levels (Article 30 paragraph 1). This provision mandated the establishment of BoDs as organs of self-management in all HEIs, both national and private. Amendments made to the 1995 Law on Higher Education on July 23, 1998 further stipulated that state-owned HEIs be led by a president nominated by the BoD and approved by the central government authority for educational administration (Article 13 paragraph 2). This positioned the $\mathrm{BoD}$ as the ultimate decision-making organ within each institution, and furthermore required the president to be nominated by the board.

With regard to the powers of the BoD, the 1995 Law on Higher Education empowered the board to determine the educational organization, training programs, and rules of the HEI (Article 10 paragraph 5). Meanwhile, the 1995 Law on Education provided that the board should determine the institution's structure, organization, staff numbers, prescription and auditing of salaries, investments, budgets, tuition, and service fees in dormitories (Article 30 paragraph 6 clauses 3 to 6 ).

A subsequent amendment of the 1995 Law on Education on February 3, 2000 added further powers, enabling the board to appoint the heads of educational organs and their affiliated organs, and to determine and revise the institution's strategies, plans, curricula, protocols, and rules in accordance with related laws and regulations (Article 30 paragraph 6 clauses 1 and 2).

According to the above, the BoD became the ultimate decision-making body responsible for a HEI's 
management and administration, with key powers in areas including personnel, budgets, appointment of the president, strategy, and rules, making it the dominant organ within the university.

It is important next to examine the powers of the BoD as of 2021. First, an April 14, 2016 amendment of the 2002 Law on Higher Education added new powers to establish sub-funds for education and research, prescribe rules regarding establishment funds, disbursements, and the monitoring of implementation (Article 12 paragraphs 12.3 and 12.4), and determine enrollment quotas (Article 7 paragraph 7.2) and the disestablishment of the HEI pursuant to the permission of the central government organ for educational administration (Article 6 paragraph 6.4 and Article 7 paragraph 7.2).

There are also powers granted to the $\mathrm{BoD}$ under the 1995 Law on Education that have been omitted in the 2002 Law on Education. More specifically, an amendment on January 3, 2003 removed the powers of the board in state-owned educational institutions to set staff numbers and salaries (Article 36 paragraph 12.2). The power to appoint the heads of organs was also deleted, and replaced by another amendment on December 9, 2016 with the power to put forward proposals to the institution's founder with regard to the appointment and dismissal of heads (Article 36 paragraph 36.13).

In summary, the establishment of the 1995 Law on Education and 1995 Law on Higher Education following the transition to democratic government resulted in the introduction of the $\mathrm{BoD}$ as the ultimate decision-making organ in each HEI. The board had important powers in the areas of organization, budget, personnel, and strategy, including to determine the structure of the institution, its staff numbers, tuition levels, rules, and plans. This made the board the dominant organization for governance of HEIs. The enactment of new Laws on Education and Higher Education in 2002 empowered the board to establish sub-funds within the institution's budget, to make disbursements and other actions in relation to them, to determine enrollment quotas and disestablishment of organs, and, in the case of national HEIs, to make proposals to the founder concerning appointment and dismissal of the president. As of 2021, the BoD still retains its position as the dominant organ of governance with many important powers.

\subsection{Provisions on Proportional Membership of the Board of Directors}

To understand the dominant organ in the higher education administrative structure, specific provisions relating to the membership of the BoD need to be examined further. After the introduction of the BoD in the $1995 \mathrm{Law}$ on Education and 1995 Law on Higher Education, the 2002 Law on Education and 2002 Law on Higher Education were established. The paragraphs below examine the rules pertaining to university governance in the 2002 Law on Education and the amendments of April and December 2016 that prompted temporary changes to the membership of the BoD.

Provisions on the governance of universities in the 2002 Law on Education did not differ greatly from those in the 1995 Law on Education, but there were some partial changes. Concretely, parents and central and local administrative authorities in the membership of the board were omitted. The new Law stipulated that the board be composed of representatives of the founder, faculty members, students, and alumni (Article 30 paragraph 1) and that 51 to $60 \%$ of members be representatives of the founder (Article 30 paragraph 2). This means that following the establishment of the 2002 Law on Education, the BoD was to be composed of representatives of the founder (comprising 51-60\% of the overall membership), students, faculty members, and alumni.

However, this membership profile was altered significantly by an amendment on April 14, 2016. The amendment stipulated that $30 \%$ of board members in state-owned HEIs, and $60 \%$ in non-state-owned HEIs, be representatives of the founder (Article 11-1 paragraph 1), and that $40 \%$ of board members in state-owned HEIs, and $10 \%$ in non-state-owned HEIs, be independent members (experts) representing the community and society and appointed for six-year terms of office. These independent members were to be appointed by the founder when the BoD first meets, and members that need to be newly appointed thereafter were to be selected by a committee established by the board, under rules approved by the central government authority for educational administration (Article 11-1 paragraph 2). Other stipulations included that $20 \%$ of the board's members must be representatives of faculty and students (Article 11-1 paragraph 3) and 10\% must be representatives of alumni (Article 11-1 paragraph 4). Applying these provisions meant that the BoD in a national HEI would be composed of $30 \%$ representatives of the founder, $40 \%$ experts representing the local community and society, $20 \%$ representatives of faculty and students, and $10 \%$ representatives of the institution's alumni.

In a private institution, the profile would be $60 \%$ founder's representatives, $10 \%$ experts representing the local community and society, $20 \%$ representatives of faculty and students, and $10 \%$ representatives of alumni. These changes were designed to ensure that independent members (experts) representing the local community and society were included on the boards of all HEIs. 
Shortly after the amendment was passed, however, a change of government led to another amendment (December 9, 2016), which reinstated the original provisions of the 2002 Law on Education, stipulating simply that the BoD be composed of representatives of the founder, faculty, students, and alumni (Article 36 paragraph 1) and that $51-60 \%$ of members be representatives of the founder (Article 36 paragraph 2).

This means that with the exception of the short period when the 2016 amendments were in place, ever since the board of directors system was first introduced in 1995, the board has been statutorily required to include representatives of the founder, faculty, students, and alumni. Representatives of the founder are required to make up $51-60 \%$ of the overall membership of the board, while the proportions of faculty, student, and alumni representatives are flexible. This has created a system in which the wishes of the founder are reflected in the governance of all HEIs in Mongolia, regardless of whether they are private or national.

Given that representatives of the founder constitute the majority (51-60\%) in the $\mathrm{BoD}$ at all HEIs, the next question which arises is: what kind of people are selected as these representatives? The actual makeup of BoDs needs to be examined in more detail.

\subsection{Board Members Appointed by the Founder}

The 2002 Law on Higher Education classifies HEIs into three categories: universities, institutes, and colleges. Universities are defined as institutions of research, education and production, or research and education, which conduct basic and applied research in several scientific fields, offer education programs at Bachelor, Master's and Doctoral levels, and have production facilities, service facilities, and laboratories (Article 4 paragraph 2). In contrast, institutes are education and research institutions that conduct research and investigation in a particular scientific field and have the right to offer education programs at Diploma and Bachelor levels. Institutes are further empowered to offer education programs at Master's level (Article 4 paragraph 3). These provisions mean that universities can be seen as comprehensive universities with the capacity to provide education up to graduate school level, while institutes are single-discipline universities focused on the undergraduate level. Colleges, meanwhile, are defined as institutions of education, or education and production, offering education programs at Diploma and Bachelor levels (Article 4 paragraph 4). As of 2021, there are 95 HEIs in Mongolia whereby 21 of these $(22.1 \%)$ are national HEIs, $71(74.7 \%)$ are private, and three $(3.2 \%)$ are branch campuses of foreign institutions.

\subsubsection{Membership of HEI Boards of Directors}

From January 1 to 14,2021 , the author reviewed information on the governance structures published on the websites of individual HEIs, with reference to the MECS' statistics on the higher education sector for FY2019-2020. The 21 national HEIs are composed of 14 universities and 7 institutes. Of these, five institutions-the National University of Commerce and Business, Khovd University, Dornod University, Mongolian Railway Institute, and Mongolian State Conservatory-list the BoD as the supreme body within their organizational structure, but do not publish the membership of the board. Moreover, three institutions - the National Defense University, University of Internal Affairs, and National Academy of Governance-do not include the board in their outlines of governance structure, and instead position the president as the ultimate decision-making authority. Information on the National Intelligence Academy is only published in one section of the General Intelligence Agency website, and does not include any information on governance.

These exceptions are related to the stipulation in the 2002 Law on Education (Article 34 paragraph 34.2) that paragraph 1 of Article 34 (which contains the provisions on the establishment of the BoD) does not apply to HEIs related to the military or police force. The rules established by individual HEIs offer further details. The National Defense University is stipulated to be an institution under the authority of the Minister of Defense which is an organ of the Mongolian government, and that the university's president has complete authority to represent the university, and that the president is appointed and dismissed by the Minister of Defense pursuant to a decision of an organ of the Civil Service Council (Minister of Defense Order A/178 of June 19, 2017 on renewal of the National Defense University Charter: Part 1 general provisions, Article 3 National Defense University, paragraph 3.2; Part 5 National Defense University administration and powers therein, Article 11 administrative powers and responsibilities, paragraphs 11.1 and 11.2). In other words, it is assumed that the National Defense University falls under the jurisdiction of the Ministry of Defense, so the statutory provisions on BoDs established by the MECS do not apply, and instead the Minister of Defense appoints a president who conducts the administrative affairs of the university.

The University of Internal Affairs was established under the Ministry of Justice and Internal Affairs, merging the Police Academy, National Intelligence Academy, and Border Troops Institute. The aim of this establishment was to improve systems for training and re-training personnel in legal affairs, internal affairs, and intelligence, and to 
improve the coordination of research activities (Decision No. 229 of the Government of Mongolia, July 6, 2011, for establishment of the University of Internal Affairs).It was further shown that the fixed assets and liquid assets of the Police Academy, National Intelligence Academy, and Border Troops Institute, together with their personnel and budgets, be transferred to the University of Internal Affairs under the jurisdiction of the Ministry of Justice and Internal Affairs (Decision No. 243 of the Government of Mongolia, August 17, 2011, for various measures pertaining to the University of Internal Affairs). Moreover, the University of Internal Affairs' organizational chart shows the Government of Mongolia at the top, with the Ministry of Justice and Internal Affairs below it, and the university itself one rung lower, alongside organizations including the National Police Agency, General Authority for Border Protection, National Archives of Mongolia, and General Executive Agency of Court Decision. In other words, like the National Defense University, the University of Internal Affairs is under the direct jurisdiction of the Ministry of Justice and Internal Affairs rather than the MECS, meaning that there is no BoD, and it is governed instead by a president appointed by the Ministry of Justice and Internal Affairs.

Finally, regarding to the National Academy of Governance, Decision No. 44 of the Government of Mongolia of September 22, 2012 specified that The National Academy of Governance be established under the Cabinet Secretariat, and be responsible for the training and re-training of civil servants providing specialized, methodological advice on policy implementation to government authorities, and the conduct of surveys, analysis, and training related to the improvement of human resource management for civil servants.

Based on the above, a BoD is not established here either, as it is a HEI under the jurisdiction of an associated ministry or agency rather than the MECS. There is no BoD in the Mongolian University of Life Sciences' affiliated Institute of Horticulture either, but rather a president, who sits in a management structure under the Institute itself, above which is the Mongolian University of Life Sciences. The absence of a BoD in this case is attributable to the fact that the Institute is an affiliated organization under the control of its parent organization, with a president appointed by the parent organization being responsible for the Institute's internal administration.

The above institutions that lack a $\mathrm{BoD}$ are excluded from the analysis that follows. Two other institutions are also excluded: The German-Mongolian Institute for Resources and Technology, which is operated with government funding from Germany and whose BoD includes representatives from the German federal government, and the Buddhist University of Mongolia, which is operated under the authority of the Gandantegchinlen Monastery in Mongolia. Resultantly, specific data on the membership of BoDs was obtained from nine national HEIs, which are analyzed below.

Of these nine institutions, six have boards composed of 15 members, while the National University of Medical Sciences has 17. The remaining two, the Institute of Labor and Social Relations and the University of Science and Technology-affiliated Erdenet Institute of Technology located in the province of Orkhon, are exceptional cases as outlined below.

First, the Institute of Labor and Social Relations has a BoD with four members (executive director of the Confederation of Mongolian Trade Unions [chairman of the board],director of the Confederation of Mongolian Trade Unions [member of board], the Medical Employees Trade Union Federation of Mongolia deputy head [alumni representative], and a faculty member of the Institute of Labor and Social Relations [faculty representative]).This Institute was founded in 1993 with the leadership of the Confederation of Mongolian Trade Unions. The distinctive makeup of the Institute's $\mathrm{BoD}$ is therefore attributable to the fact that it operates under the jurisdiction of the Confederation of Mongolian Trade Unions. Meanwhile, The Erdenet Institute of Technology describes itself as an educational institute for the training of personnel for the Erdenet Mining Corporation, Mongolia's largest — and the world's 26th largest—-state-owned copper mining corporation, which is involved in the corporation's education, research and production activities. For this reason, the Erdenet Institute's BoD is composed almost entirely of members affiliated with the Erdenet Mining Corporation.

Apart from these two special cases of the Institute of Labor and Social Relations and the School of Technology, Erdenet, the remaining seven institutions maintain boards of 15 or 17 members, regardless of their number of faculties or fields of specialization. Out of the combined total of 107 members (the same individual associated with the MECS is a member of the board at a number of different institutions) making up these seven institutions' boards, $62(57.9 \%)$ are founder's representatives, $32(29.9 \%)$ are representatives of students and faculty, and 13 $(12.1 \%)$ are alumni representatives.

Generally, a company president who has graduated from this institution is appointed as the representative of the alumni. This is considered to improve the content and quality of university education and to meet the employment needs and enrollment needs of graduates according to the market (former MECS officer, personal 
communication, April 10, 2021). As such, the response to marketization is also taken into consideration.

This shows that as a whole, the proportion of founder's representatives is within the statutorily required range of 51 to $60 \%$.

Membership of BoDs in private HEIs is examined next. The 71 private HEIs in Mongolia are composed of 21 universities, 43 institutes, and 7 colleges. Two of these are excluded from the analysis below because they are branch campuses of foreign institutions. Another 13 are excluded because they do not have websites, making it impossible to check the BoD's membership. Another 14 have BoDs as their ultimate decision-making body but do not publish the membership of their boards, while 25 do not publish information on the existence or otherwise boards. The following were also excluded from the analysis. The Institute of Sociology and Psychology: this institution states that it has a $\mathrm{BoD}$ as the ultimate decision-making body, composed of nine members including representatives of faculty, students, alumni, and its founder, but does not provide any further breakdown. Two final exclusions were the Institute of Cinematography and the Institute of Engineering and Technology, which are atypical in that in both cases the BoD is organizationally subordinate to a general shareholders' meeting, and no details of board membership is provided. It was possible to obtain specific information on board membership from the remaining 14 private HEIs, and these data form the basis of the analysis below.

Board membership in these institutions was not classified into representative types such as a representative of the founder, representative of faculty, and the like, so the author contacted the institutions directly to confirm the details. This revealed that out of a combined total of 147 board members at these institutions, $115(78.3 \%)$ were founder's representatives, $24(16.3 \%)$ were representatives of students and faculty, and $8(5.4 \%)$ were representatives of alumni. As a whole, therefore, the proportion of founder's representatives, $78.3 \%$, significantly exceeds the statutory range of 51-60\%. Table 1 summarizes these findings on board membership in HEIs.

Table 1. Membership of the Board of Directors in HEIs

\begin{tabular}{lllll}
\hline Institution Type & Institutions Analyzed & \multicolumn{3}{l}{ Proportion of Board Membership } \\
\cline { 3 - 5 } & & $\begin{array}{l}\text { Representatives } \\
\text { of Founder }\end{array}$ & $\begin{array}{l}\text { Representatives of } \\
\text { Faculty/Students }\end{array}$ & $\begin{array}{l}\text { Representatives } \\
\text { of Alumni }\end{array}$ \\
\hline National & 7 & $57.9 \%$ & $29.9 \%$ & $12.1 \%$ \\
Private & 14 & $78.9 \%$ & $15.7 \%$ & $5.4 \%$ \\
\hline
\end{tabular}

\subsubsection{Founder's Representatives in Boards of Directors}

In national HEIs, a variety of individuals are selected as founder's representatives, and it is possible to assign them to a number of categories based on their affiliation. The first question is whether or not an individual is a government official. Government Officials can be further divided into three categories: those affiliated with the MECS (educational officials), those affiliated with the Cabinet Secretariat (central government officials), and those affiliated with other ministries and agencies (other ministerial officials). Non-government officials include researchers, professionals, and others, but here they are grouped in a single category of disciplinary experts. This produces four categories in all, to frame the discussion below.

Using the categories defined above, the 62 representatives of the founder in national HEIs can be divided into 10 central government officials (16.1\%), 17 educational officials (27.4\%), 12 other ministerial officials (19.4\%), and 23 disciplinary experts $(37.1 \%)$. This shows that founder's representatives include large numbers of disciplinary experts as well as a variety of members of governmental organs.

Table 2 presents the cases of three national universities (National University of Mongolia, National University of Medical Sciences, and the Mongolian University of Life Sciences) as examples of the specific breakdown of board members. The first thing apparent from this table is that following the trend of all seven institutions, many of the government officials on the board are selected from outside the MECS. The single-discipline universities (medicine and agriculture) in particular have government officials from their associated ministries and agencies and researchers from the disciplines in question, while the comprehensive university has a number of central government officials. In other words, not only do a variety of individuals serve as board members, but the members are selected widely from areas connected with each university. In that regard, national universities are promoting the inclusion of government officials other than from the MECS and disciplinary experts in order to carry out broader activities and joint activities toward globalization, marketization, and society (MECS officer, personal communication, September 16, 2020). 
Table 2. Makeup of Founder's Representatives on National HEI Boards of Directors: Three Examples

\begin{tabular}{|c|c|c|c|}
\hline Category & $\begin{array}{lll}\text { National } & \text { University } & \text { of } \\
\text { Mongolia } & & \\
\end{array}$ & $\begin{array}{l}\text { National University of } \\
\text { Medical Sciences }\end{array}$ & $\begin{array}{llll}\begin{array}{l}\text { Mongolian } \\
\text { Sciences }\end{array} & \text { University of } & \text { Life } \\
\end{array}$ \\
\hline $\begin{array}{l}\text { Central } \\
\text { government } \\
\text { officials }\end{array}$ & $\begin{array}{l}\text { Member of Civil Service } \\
\text { Council, } \\
\text { Director-General of the } \\
\text { Office of the Government, } \\
\text { Director of the Legal } \\
\text { Affairs Division of the } \\
\text { Office of the Government }\end{array}$ & - & $\begin{array}{l}\text { Senior Consultant and Director of the } \\
\text { Office of the Prime Minister }\end{array}$ \\
\hline $\begin{array}{l}\text { Educational } \\
\text { officials }\end{array}$ & $\begin{array}{l}\text { Advisor to the Minister of } \\
\text { Education, Culture, Science } \\
\text { and Sports, Deputy Director } \\
\text { of the Science and } \\
\text { Technology Bureau of the } \\
\text { MECS }\end{array}$ & $\begin{array}{l}\text { Secretary of State of the } \\
\text { MECS, Acting Director } \\
\text { of Innovation and } \\
\text { Technology of the } \\
\text { MECS, Culture, } \\
\text { Science and Sports, } \\
\text { Acting Director of } \\
\text { Legal Affairs of the } \\
\text { MECS }\end{array}$ & $\begin{array}{l}\text { Director of the Production Bureau of } \\
\text { the MECS, Director of the Science } \\
\text { and Technology Bureau of the MECS }\end{array}$ \\
\hline $\begin{array}{l}\text { Other } \\
\text { ministerial } \\
\text { officials }\end{array}$ & $\begin{array}{l}\text { Secretary of State of the } \\
\text { Ministry of Finance }\end{array}$ & $\begin{array}{l}\text { Director of the } \\
\text { Inspection Agency, } \\
\text { Advisor to the Ministry } \\
\text { of Health, Head of the } \\
\text { Budgetary Expenditure } \\
\text { Office of the Ministry } \\
\text { of Finance }\end{array}$ & $\begin{array}{l}\text { Head of the Expenditure Division, } \\
\text { Budgetary Policy Bureau, Ministry of } \\
\text { Finance, Director of the Agricultural } \\
\text { Policy Coordination Bureau of the } \\
\text { Ministry of Agriculture }\end{array}$ \\
\hline $\begin{array}{l}\text { Disciplinary } \\
\text { experts }\end{array}$ & $\begin{array}{l}\text { Director of the Institute of } \\
\text { History and Ethnology, } \\
\text { Mongolian Academy of } \\
\text { Sciences, Director of the } \\
\text { Mongolian Science and } \\
\text { Technology Foundation }\end{array}$ & $\begin{array}{l}\text { Director of the State } \\
\text { Central Second Hospital }\end{array}$ & $\begin{array}{l}\text { Deputy Secretary-General of the } \\
\text { Mongolian Farmers and Millers } \\
\text { Association, Director of the Plant } \\
\text { Conservation Research Institute, } \\
\text { Scientists' Secretary of the Mongolian } \\
\text { Academy of Sciences, Head of the } \\
\text { Administrative Studies Department of } \\
\text { National Academy of Governance }\end{array}$ \\
\hline
\end{tabular}

Note. Created by the author based on board membership information provided on the universities' websites.

Next is an examination of founders' representatives on the boards of private HEIs. A diverse range of individuals are selected as founder's representatives in these institutions, and can also be divided into a number of categories based on their affiliation. The first distinction is whether or not they are affiliated with the institution itself. Those who are affiliated can be divided further into the categories of: (1) faculty members, and (2) permanent executive officers and administrators (including the institution's founder, president, vice presidents, program deans, financial affairs director, administrative affairs division personnel; referred to below simply as "executives/administrators"). Those not affiliated with the institution can be divided into the categories of (3) businesspeople, (4) professionals (lawyers, researchers, professors at other universities, etc.), and (5) government officials. These five categories frame the discussion below.

Using the categories defined above, the 115 representatives of the founder in private HEIs can be divided into internal representatives comprising 18 faculty members (15.6\%) and 53 executives/administrators (46.1\%), and external representatives comprising 21 businesspeople (18.3\%), 14 professionals (12.2\%), and 9 government officials $(7.8 \%)$. This shows that most of the founder's representatives on the board are selected from within the institution, and especially from among executives/administrators. Table 3 presents the breakdown for three institutions as examples: Ikh Zasag International University, Otgontenger University, and the Institute of Technology. 
Table 3. Makeup of Founder's Representatives on Private HEI Boards of Directors: Three Examples

\begin{tabular}{|c|c|c|c|c|}
\hline \multicolumn{2}{|l|}{ Category } & $\begin{array}{l}\text { Ikh Zasag } \\
\text { International } \\
\text { University } \\
\text { Dean of College of }\end{array}$ & \multirow{2}{*}{$\begin{array}{l}\text { Otgontenger University } \\
\text { Faculty member of } \\
\text { School of Law }\end{array}$} & \multirow{2}{*}{$\begin{array}{l}\text { Institute of Technology } \\
-\end{array}$} \\
\hline Internal & Faculty & $\begin{array}{l}\text { Dean of College of } \\
\text { Finance and } \\
\text { Economics, Dean } \\
\text { of College of Law, } \\
\text { head of affiliated } \\
\text { Jesan school of } \\
\text { vocational training }\end{array}$ & & \\
\hline & $\begin{array}{l}\text { Executives/ } \\
\text { administrators }\end{array}$ & $\begin{array}{l}\text { President, Vice } \\
\text { President, Director } \\
\text { of Financial Affairs, } \\
\text { Associate of the } \\
\text { founder }\end{array}$ & $\begin{array}{l}\text { Chairman/founder, } \\
\text { President, Vice } \\
\text { President for Policy, } \\
\text { Planning, } \\
\text { Investment, Director of } \\
\text { Financial Affairs, } \\
\text { Projects, and Services }\end{array}$ & $\begin{array}{l}\text { Chairman/founder, President, } \\
\text { Dean of Educational Activities, } \\
\text { Dean of Research and Innovation }\end{array}$ \\
\hline \multirow[t]{3}{*}{ External } & $\begin{array}{l}\text { Business } \\
\text { people }\end{array}$ & - & $\begin{array}{l}\text { Executive Director of a } \\
\text { Clean energy company }\end{array}$ & $\begin{array}{l}\text { President of NVTs Group (an egg } \\
\text { company), general manager of a } \\
\text { "Talkh Chikher" JSC } \\
\text { (confectionary "Hunsmash" JSC } \\
\text { president of a "Hunshy } \\
\text { (meat and food products } \\
\text { company), vice president for } \\
\text { marketing/sales and procurement } \\
\text { of a "SUU" JSC (milk and dairy } \\
\text { products company), president of } \\
\text { a "Khuns complex" LLC (ham } \\
\text { and sausage production } \\
\text { company) }\end{array}$ \\
\hline & Professionals & $\begin{array}{l}\text { Advisor to the } \\
\text { president }\end{array}$ & Scholars of education & $\begin{array}{l}\text { President of the Mongolian } \\
\text { Hospitality Association, } \\
\text { President of the Mongolian Chefs } \\
\text { Association, Vice President for } \\
\text { Education of the Mongolian } \\
\text { National University of Education }\end{array}$ \\
\hline & $\begin{array}{l}\text { Government } \\
\text { officials }\end{array}$ & $\begin{array}{l}\text { National } \\
\text { parliamentarian } \\
\text { (son of the founder) }\end{array}$ & - & $\begin{array}{l}\text { Secretary of the Ministry of } \\
\text { Food, Agriculture and Light } \\
\text { Industry }\end{array}$ \\
\hline
\end{tabular}

Note. Created by the author based on board membership information provided on the universities' websites

It is apparent from Table 3 that following the trend in all 14 institutions, indicate that significant numbers of board members are selected from within the institution, while in some cases the number of representatives of external businesses is notably high.

Institutions with large numbers of representatives from business include not only the Institute of Technology, which is a small-scale institution in a specialized field, but also the University of Pharmaceutical Sciences ${ }^{20}$. The founder of this university is a business operator who also owns a large number of companies engaged in the production and sale of pharmaceuticals. It is safe to say that the university was founded in order to undertake research activities and personnel training for these companies.

When institutions with a large number of external business representatives (the Institute of Technology and University of Pharmaceutical Sciences) are excluded, the founder's representatives on the BoD are appointed 
mainly from among faculty and permanent staff members within the institution. A notable feature, therefore, is that founders are appointing internal faculty and staff members to the board as their representatives, despite the statutory stipulation that internal faculty members also be appointed to the board under a separate category from the majority appointed by the founder.

\subsubsection{Comparison of Members of the Board Appointed by HEI Founders}

The comparative data, as shown in Table 4 below offer an overview of how the profile of founder's representatives on the BoD differs in line with institution type.

Table 4. Makeup of Founder's Representatives on the Board of Directors by Type

\begin{tabular}{|c|c|c|c|c|c|c|c|}
\hline \multirow{4}{*}{$\begin{array}{l}\text { Institution } \\
\text { Type }\end{array}$} & \multicolumn{7}{|c|}{ Founder's Representatives (profile of the $51-60 \%$ of board members) } \\
\hline & \multirow{2}{*}{\multicolumn{2}{|c|}{ Internal }} & \multicolumn{5}{|c|}{ External } \\
\hline & & & \multicolumn{3}{|c|}{ Government Officials } & \multirow[t]{2}{*}{ Business-people } & \multirow[t]{2}{*}{ Professionals } \\
\hline & Faculty & $\begin{array}{l}\text { Executives/ } \\
\text { Administrators }\end{array}$ & $\begin{array}{l}\text { Central } \\
\text { Govt. }\end{array}$ & Education & Other & & \\
\hline National & - & - & $16.1 \%$ & $27.4 \%$ & $19.4 \%$ & - & $37.1 \%$ \\
\hline Private & $15.6 \%$ & $46.1 \%$ & - & $7.8 \%$ & - & $18.3 \%$ & $12.2 \%$ \\
\hline
\end{tabular}

Table 4 shows that in national HEIs, founder's representatives on the BoD are composed of people external to the institution, with government officials accounting for the largest proportion at $62.9 \%$. In private institutions, on the other hand, founder's representatives are drawn from both within and outside the institution, with the majority of $61.7 \%$, being internal faculty, executives, and administrators. In both national and private institutions, a certain proportion of founder's representatives are people associated with the institution's fields of specialization, while in private institutions a number of board members are businesspeople.

The above analysis reveals a fundamental difference between private and national HEIs: in private institutions the majority of founder's representatives on the BoD are internal faculty, executives, and administrators, while in the national institutions the majority are government officials.

\section{Discussion}

This article has shed light on the positioning of the $\mathrm{BoD}$ as an organ of governance in Mongolian HEIs, focusing mainly on analysis of board members representing the institution's founder. First, the powers of the BoD and how they have changed over time was discussed, referring to statutory provisions since the introduction of the board of directors system. Following this, specific statutory provisions on the proportions of different types of board members were examined. Last, analysis was conducted on the membership of the board in different types of institution, and the profile of members representing the founder, as well as a comparison to reveal differences in the profile of founder's representatives on the board across the different types of institution.

This analysis produced the following findings. First, the BoD, which was introduced under the 1995 Law on Education and 1995 Law on Higher Education, is now the dominant organ within HEIs. It is empowered, among other things, to determine the institution's budgets, personnel, and long-term plans, propose the appointment and dismissal of the president, and appoint the heads of organizations affiliated with the institution.

Positioned as the dominant and ultimate decision-making body, the $\mathrm{BoD}$ is required to have $51-60 \%$ of its members as representatives of the institution's founder, while the remaining members are to be representatives of the faculty, students, and alumni of the institution. This can be seen as a mechanism for reflecting the wishes of the institution's founder in the governance of all HEIs in Mongolia, both national and private, within the scope of statutory provisions.

Furthermore, by type, in the case of national universities, 51-60\% of board members are representatives of the MECS, and in the case of private universities, the same percentage are representatives of the founders of the institution. However, analysis of the actual situation of the representatives of the founders revealed that a large proportion of external administrative officers and directors of specialized fields have been appointed to the BoD of national HEIs. It was also found that few educational officials belong to the MECS as directors of administrative officers and many other governmental administrative participants. Rather than selecting directors concerning the MECS and the university, it is necessary for directors to relate to the activities of the university, such as the medical field at medical universities, and be selected from among all government agencies, allowing a wide range of human resources to participate.

Conversely, it was found that the ratio of internal directors is high in private HEIs, with faculty, executives, and 
administrators appointed. Although there is a legal framework for representatives of faculty members to be directors, more internal directors, including faculty members, are selected even in the category of representatives of the founder. This can be said to be a feature of private HEI BoDs.

Based on the above, the following conclusions can be made. With globalization, social change, and the penetration of market principles, university governance reforms are being promoted throughout in the world. The establishment of the BoD as the highest decision-making body of HEIs in Mongolia is part of this worldwide trend. In the case of national universities, many of the directors are government officials. In particular, by appointing a large number of government officials and directors in specialized fields related to the institution, the control by the government will be strict and the autonomy of universities will be weakened, but may assist them in trying to cope with globalization and marketization. In addition, it was also found that alumni who had become company presidents were appointed to the board by HEIs trying to take advantage of market opportunities.

The following differences between national HEIs and private HEIs were observed. There is a decisive difference in that private HEIs are dominated by internal directors such as faculty members, executives, and administrators as representatives of the founders, while national HEIs are dominated by government officials. This is because there are many government officials at national universities, so in a sense, the university lacks autonomy, but it has the advantage of being responsive to globalization and marketization. However, in the case of private universities, since the board is composed of members within the university, it has a strong self-government aspect, but it is rather difficult and slow to respond to internationalization and globalization.

The detailed analysis of the membership of the $\mathrm{BoD}$ in this article involved classifying HEIs based on whether or not they have a BoD and whose jurisdiction they are under, and considering what kinds of ideas are reflected in their governance. This analysis revealed a wide variety of governance structures, including exceptional cases such as national institutions which are operated in partnership with other organizations - the Institute of Labor and Social Relations is one example - and private institutions where the BoD is positioned under a general shareholders' meeting. This shows that as governance reforms are advanced in universities across the world, at least in Mongolia, the simple categories conventionally used to classify HEIs, such as national and private, large and small, are proving inadequate. There is a need to determine categories based on systems of governance and pursue discussion taking into account the actual systems in operation at different institutions. Future research is therefore required to define categories based on systems of governance to encompass those institutions that could not be included in the analysis in this paper and to elucidate their features in practice.

\section{Acknowledgements}

I would like to thank Simul International (www.simul.co.jp) for English language editing, and Kyoto University, Graduate School of Education's Global Education Office, for providing full funding opportunities for language editing.

\section{References}

Balgan, A. (2019). Governance in Mongolian Higher Education: A Comparative Analysis. International Journal of Higher Education, 8(3), 185-190. https://doi.org/10.5430/ijhe.v8n3p185

Baterdene, B., \& Erdenebulgan, J. (2018). Deed bolowsroliin zasaglal erkh zuin asuudal, shiidel [Higher Education governance legal issues and solutions]. Paper presented at II National Conference on Sustainable Development-Higher Education,Mongolia,Ulaanbaatar.

Ehara, T., \& Sugimoto, H. (2005). Daigaku no Kanri Unei Kaikaku: Nihon no Yukue to Shogaikoku no Doukou [University Governance Reforms: Directions in Japan and Trends in Other Countries]. Tokyo, Japan: Toshindo.

Erdenet Institute of Technology. (2021). Retrieved from http://erdenetis.edu.mn/History.aspx

Fujimura, M. (2008). Sujin - dairininronkara mita koutoukyoshisutemu-jiritsu to izonno paradokusu [Higher Education Systems as a Principal-Agent Relationship: The Paradox of Autonomy and Dependence]. Daigaku Ronshuи [Research in Higher Education]. Hiroshima University Research Institute for Higher Education, 39,185-203. Retrieved from https://rihe.hiroshima-u.ac.jp/search/attachfile/89716.pdf

Ikh Zasag International University. (2021). Retrieved from https://ikhzasag.edu.mn/administration

Institute of Labor and Social Relations. (2021). Retrieved from https://mlsri.edu.mn/about/

Institute of Sociology and Psychology. (2021). Retrieved from https://www.usp.mn/aboutusp?pgid=jyg0h8z2-2661d627-18c8-4c64-a44f-ec0843189939 
Institute of Technology. (2021). Retrieved from https://www.itech.edu.mn/mn/index.php?pid=95

Jargalmaa, J. (2019). Mongoru no Daigaku no Kanri Unei Seido ni kansuru Kousatsu-Taisei Ikou no Hikakuteki Kentou o Tsuujite-[Consideration on Governance System of University in Mongolia: Through Comparative of System Transition]. Kyoto University Research Studies in Education, 65, 233-245. Retrieved from https://repository.kulib.kyoto-u.ac.jp/dspace/bitstream/2433/240810/1/eda65_233.pdf

Law on Education. (2002). Laws of Mongolia on the integrated legal information system. Retrieved from https://www.legalinfo.mn/law/details/9020

Law on Higher Education. (1995). Laws of Mongolia on the integrated legal information system. Retrieved from https://www.legalinfo.mn/law/details/7091

MECS. (2012). Bolowsroliin salbariin erh zuin tuuhiin eh surwalj [Sources of Legal History in the Field of Education]. Ulaanbaatar, Mongolia: Ganprint Publishing.

MECS. (2020). Statistical report of higher education sector, 2019-2020.

Mongolian National University of Medical Sciences. (2021). Retrieved from http://www.mnums.edu.mn/?page_id=6750.

Mongolian University of Life Sciences. (2021). Retrieved from https://muls.edu.mn/view.php?page_value_sub=ZW5jb2RldXNlcmlkMTM=)

Munkh-Erdene, L. (2008). Reforming State university governance: public status and shared governance, Policy Analyses. Open Society Forum. Retrieved from http://pdc.ceu.hu/archive/00006324/01/Reforming_State_University_Mongolia.pdf

National University of Mongolia. (2021). Retrieved from https://www.num.edu.mn/content.htm?mid=43

Otgontenger University. (2021). Retrieved from https://www.otgontenger.edu.mn/mn/about/administration

University of Pharmaceutical Sciences. (2021). https://monos.edu.mn/

Yamasaki, H. (1996). Daigaku Houjin Rijikai no Yakuin Kousei to sono Kouzou Henka [Occupational Composition of Board of Trustees in Japanese Private School], Daigaku Ronshuu [Research in Higher Education]. Hiroshima University Research Institute for Higher Education, 25, 303-320. https://doi.org/10.15027/27499

\section{Copyrights}

Copyright for this article is retained by the author(s), with first publication rights granted to the journal.

This is an open-access article distributed under the terms and conditions of the Creative Commons Attribution license (http://creativecommons.org/licenses/by/4.0/). 